Vol. 19 (2009): 34-42.

\title{
Efficacy of fungicide tebuconazole in barley varieties with different resistance level
}

\author{
Pille Sooväli ${ }^{1,2^{*}}$ and Mati Koppel ${ }^{1}$ \\ ${ }^{1}$ Jõgeva Plant Breeding Institute, Aamisepa 1, 48309 Jõgeva, Estonia \\ ${ }^{2}$ Institute of Agricultural and Environmental Sciences, Estonian University of Life Sciences, Kreutzwaldi 1, \\ 51014 Tartu, Estonia, *e-mail: Pille.Soovali@jpbi.ee
}

\begin{abstract}
Efficacy of the fungicide tebuconazole was tested in 2 treatment regimes in 3 spring barley varieties over three years (2003-2005). The impact of the fungicide on the control of major barley pathogens Pyrenophora teres and Cochliobolus sativus, as well as kernel yield was studied in the course of field trials. The fungicide treatments had a strong impact on the control of infection of $P$. teres and increased kernel yield in variable disease infection conditions. For the more resistant genotype, fungicide application had relatively low returns because of the much higher level of biological resistance and small disease-related yield reductions. For the susceptible genotype, severe disease infection caused bigger yield reduction, not compensated by the use of fungicides. Use of fungicide demonstrated the highest economic return in the case of the moderately susceptible barley variety.
\end{abstract}

Key-words: spring barley, net and spot blotch, tebuconazole, application time, yield, quality

\section{Introduction}

Spring barley is the prevailing spring crop in Estonia, with growing area of 128.2 thousand ha, occupying $48.2 \%$ of the total area under cereals in 2004 (www.stat.ee). In Estonian conditions, spot blotch, caused by Cochliobolus sativus (Ito \& Kurib.) Drechsler, am Bipolaris sorokiana (Sacc.) Shoem.
Syn. Helminthosporium sativum P.K. et B) and net blotch, caused by Pyrenophora teres Drechsl. am. Drechlera teres (Sacc.) Shoem. (Palmer 1989, Mathre 1997), are serious foliar diseases of barley (Hordeum vulgare), causing serious yield and quality reduction. Both pathogens are mainly controlled by fungicide treatments. Estonian disease monitoring of the last decade has shown that the occurrence of net blotch is increasing, which is directly related 
Vol. 18 (2009): 34-42.

to the grown cultivars (Tamm 2003). Other common barley diseases - powdery mildew (Erysiphe graminis f. sp. hordei E.M. Syn. Blumeria graminis (DC) E.O. Speer f.sp. hordei E.M.) (Mathre 1997) and scald (Rhynchosporium secalis (Oudem.) J.J. Davis) (Mathre 1997) - have been rather infrequent during the last years and have rarely crossed the threshold of economic importance.

Net blotch has been widely spread in particular years and is a serious problem in untreated fields. The first symptoms of $P$. teres can be seen in barley leaves starting from GS 12, the symptoms of $C$. sativus normally develop at later growth stages, in Estonian conditions after GS 37-39. The time and level of disease infection in the field depends on the susceptibility of the used variety, therefore the resistance of varieties has a great importance in the control of plant diseases. Use of fungicides reduces the occurrence of fungal diseases and thereby reduces yield losses, increasing the economic profit. Economic profitability of fungicide use in spring barley is questionable during the years less suitable for disease development. The best disease control and yield increase are achieved by fungicide application at the early and late development stages of the crop plant (split application) but because of the high costs of fungicide application, the economic result could often be negative. Trial results from several countries have shown that despite of achieved yield increase, the high cost of fungicide application does often result in negative net revenue (Jørgensen 2006, Tischner et al. 2006, Laine et al. 2007). Higher net revenue is achieved by use of reduced fungicide doses at a later stage of plant development (after GS 37).

The aim of the study was to find out the efficacy of fungicides at different disease control intensities on spring barley varieties differing in the resistance level.

Fungicide trials usually deal with the effect of different fungicides and their doses on reduction of disease incidence and increase of yield or net revenue. Less attention is paid to the influence of the variety on the size of harvested yield and formation of net revenue. The objective of this study was to find out whether fungicide treatments would be justified in relation to the low grain prices in Estonia.
In our study we used split application of tebuconazole (250 g. a.i.; trade name in Estonia: Folicur $250 \mathrm{EW})$ and reduced doses of the fungicide recommended by decision support system PC-Plant Protection (PC-P) (Jørgensen et al. 2003). PC-P adjusts the fungicide dose according to the variety resistance, growth stage, disease pressure and efficacy of fungicide. Split fungicide application provides long-lasting protection and has the best effect in control of diseases but compared to other treatment regimes, the cost of application is higher. $\mathrm{PC}-\mathrm{P}$ is designed to recommend the minimum fungicide dose during the critical stage of disease development to restrict the development of diseases and to achieve the highest economic returns.

Implementation of integrated control strategies needs comprehensive studies on the efficacy of plant protection on varieties with different resistance levels and at different application intensities.

\section{Material and methods}

Field trials on disease control of spring barley were arranged with three replicates in a randomized design $20 \mathrm{~m}^{2}$ plots at the rate of 500 germinating seeds per $1 \mathrm{~m}^{2}$ at Jõgeva Plant Breeding Institute during the three seasons of 2003-2005. Three tworow spring barley varieties with different resistance levels were used: Anni (moderately resistant to net and spot blotch), Barke (moderately susceptible to net and spot blotch) and Extract (susceptible to net and spot blotch). Untreated certified seed was used for all varieties. The varieties were selected based on data from previous disease scoring trials in the same region (Tamm 2003). Fungicide application was started upon the first symptoms of infection (Table1). The effect of split application of tebuconazole $0.51 \mathrm{ha}^{-1}$ at stages BBCH 32-51 (T1) and BBCH 57-65 (T2) was compared with the effect of reduced fungicide dose recommended by the decision support system PC-P for controlling disease infections on moderately susceptible barley varieties. For the PC-P treatments, the same fungicide dose and application time was used for 
Sooväli, P. Fungicide tebuconazole in barley

Table 1. Time of fungicide application and assessment of disease infection (dates, growth stages BBCH) for trials of 2003-2005.

\begin{tabular}{|c|c|c|c|c|}
\hline $\begin{array}{l}\text { Number of } \\
\text { Assessment }\end{array}$ & Date & $\begin{array}{l}\text { Growth } \\
\text { stages }(\mathrm{BBCH})\end{array}$ & Fungicide dose, 1 ha $^{-1}$ & Term of disease scoring \\
\hline \multicolumn{5}{|l|}{2003} \\
\hline I & $27 / 6$ & GS $32-33$ & $\mathrm{~T} 1$ - tebuconazole $0.51 \mathrm{ha}^{-1}$ & \\
\hline II & $16 / 7$ & GS 57 & $\mathrm{~T} 2$ - tebuconazole $0.51 \mathrm{ha}^{-1}$ & \\
\hline & & & Reduced dose - tebuconazole $0.31 \mathrm{ha}^{-1}$ & \\
\hline III & $25 / 7$ & GS 71-73 & - & $\begin{array}{l}30 \text { days after T1, } 10 \text { days after } \\
\text { T2 and Reduced dose }\end{array}$ \\
\hline \multicolumn{5}{|l|}{2004} \\
\hline I & $9 / 7$ & GS 51 & $\mathrm{~T} 1$ - tebuconazole $0.51 \mathrm{ha}^{-1}$ & \\
\hline II & $21 / 7$ & GS 65 & $\mathrm{~T} 2$ - tebuconazole $0.51 \mathrm{ha}^{-1}$ & \\
\hline III & $16 / 7$ & GS 59 & Reduced dose - tebuconazole $0.161 \mathrm{ha}^{-1}$ & \\
\hline IV & $17 / 8$ & GS 75 & - & $\begin{array}{l}40 \text { days after } \mathrm{T} 1,30 \text { days after } \\
\mathrm{T} 2 \text { and Reduced dose }\end{array}$ \\
\hline \multicolumn{5}{|l|}{2005} \\
\hline I & $26 / 6$ & GS $35-37$ & $\mathrm{~T} 1$ - tebuconazole $0.51 \mathrm{ha}^{-1}$ & \\
\hline \multirow[t]{2}{*}{ II } & $18 / 7$ & GS $61-65$ & $\mathrm{~T} 2$ - tebuconazole $0.51 \mathrm{ha}^{-1}$ & \\
\hline & & & Reduced dose - tebuconazole 0.151 ha $^{-1}$ & \\
\hline III & $1 / 8$ & GS $73-75$ & - & $\begin{array}{l}40 \text { days after } \mathrm{T} 1,10 \text { days after } \\
\mathrm{T} 2 \text { and Reduced dose }\end{array}$ \\
\hline
\end{tabular}

T1 - first, T2 - second treatment.

all three varieties. Phenological growth stages were determined according to BBCH-identification keys for cereals (when $>50 \%$ of the plants had reached the target growth stage). Fungicides were applied with a bicycle sprayer equipped with 6 Hardy nozzles $4110-12$ on a $2.5-\mathrm{m}$ boom using 3001 of water per ha' ${ }^{-1}$.

Disease infection was scored as the percent of leaf area infected by $P$. teres and $C$. sativus at GS 71-75. The three top leaves of the plant were assessed separately on three adjacent tillers at 10 randomly selected places on each plot. The infection level was expressed as an average of the infection score on second leaves (L-2; the first leaf under the flag leaf). The lesions of net blotch were determined according description of Tekauz (1986). The symptoms caused by $C$. sativus were distinguished from net blotch spot type according to relative size of lesion and presence of necrosis and chlorosis. Lesions with marginal chlorosis bearing character of moderately resistant or more susceptible in- fection response according to scales of Fetch and Steffenson (1999) had classified to be caused by C. sativus. The identification was confirmed by examination of lesions under the microscope for spore production after incubation of leaves with disease symptoms in moisture chamber.

Trials were harvested with a plot combine harvester and the grain yield was adjusted to $\mathrm{kgha}^{-1}$. Qualitative and quantitative analysis of the yield parameters was conducted on dried and cleaned seeds and expressed on the basis of $14 \%$ moisture content. The net yield (harvested yield minus the cost of fungicide and application) was calculated in $\mathrm{kg} \mathrm{ha}^{-1}$. The average price of barley (0.1 EUR/ $\mathrm{kg}^{-1}$ ) in Estonia for the period 2003-2005 was used for calculating the yield revenue. The costs of the fungicide and work (7.7 EUR/ha) were subtracted from the value of the yield increase achieved with the fungicides. All prices were used without VAT.

The data were analyzed with ANOVA, using Agrobase 20 software package. 
Vol. 18 (2009): 34-42.

\section{Results}

\section{Disease development}

Net blotch (P. teres) infection dominated during all the years. The infection was more severe in 2003 and 2004 when it was promoted by high relative humidity and high air temperature (Fig.1a). As expected, in both years, the highest infection levels were observed in the variety Extract (untreated 12.7 and $43.6 \%$ respectively). The biggest difference between varieties in terms of infection was observed in 2004 (Fig.1b) when more susceptible varieties Barke and Extract were strongly infected. Hot and dry July limited development of $P$. teres in 2005 when only slight damage by net blotch infection was observed. Only minimal infection occurred on Anni and Extract (untreated 1.5 and $1.7 \%$ respectively), infection level in Barke was 2.7\% (Fig.1c).

Spot blotch infection caused by C. sativus was observed during all the years (Fig. 2). The infection reached a significant level only in 2004 when C. sativus occupied $19.3-42.8 \%$ of leaf area for untreated varieties. Spot blotch infection level was low in 2003 and 2005, being the highest in the susceptible variety Extract. Based on infection levels of both diseases, the trial years can be classified in the following terms: 2003 - medium infection, 2004 - severe infection and 2005 - slight infection.
Net blotch, \% of L2 area diseased 2003

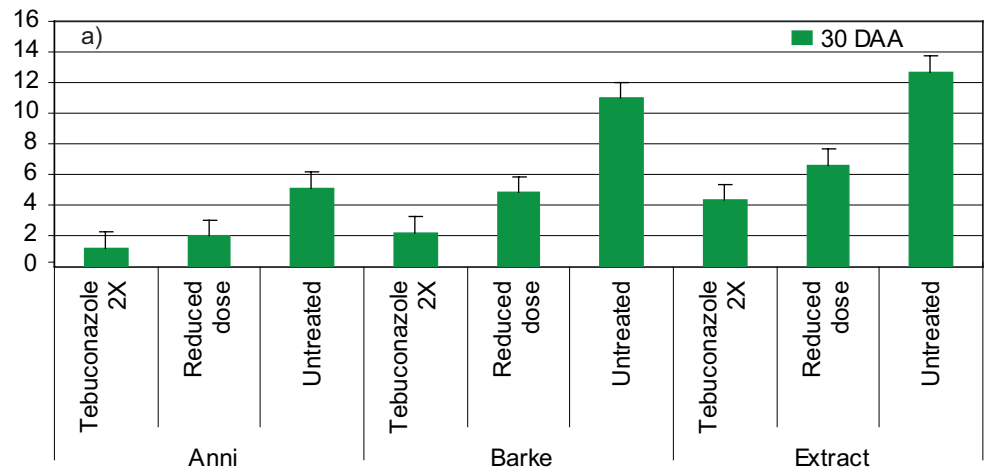

Net blotch, \% of L2 area diseased 2004

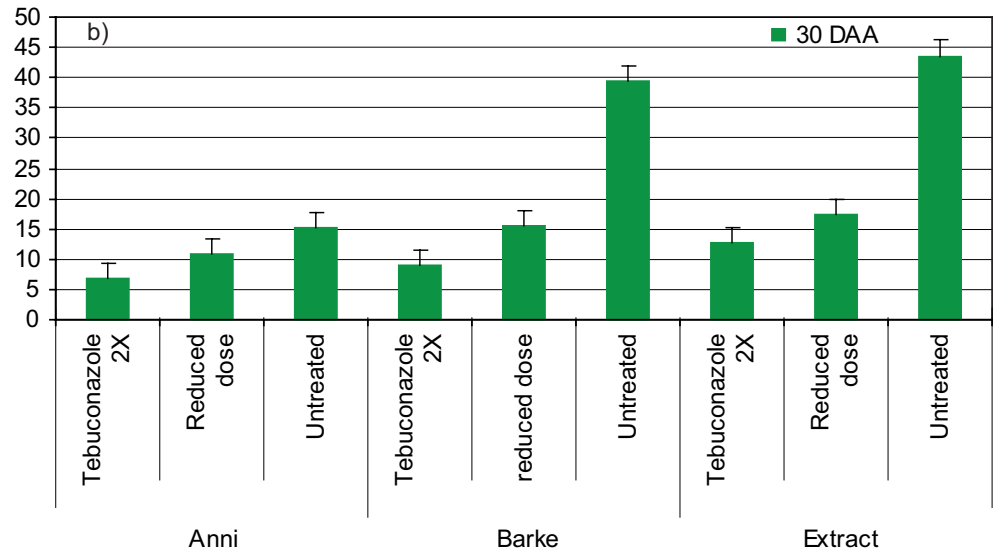

Fig. 1a. Efficacy of tebuconazole application against $P$. teres and untreated control on L2 leaves in spring barley varieties in 2003. L2= first leaf under flag leaf. DAA = days after application. Anni moderately resistant, Barke moderately susceptible, Extract susceptible to net blotch. I - LSD0.05 =1.04.

Fig. 1b. Efficacy of tebuconazole application against $P$. teres and untreated control on L2 leaves in spring barley varieties in 2004 . L2 = first leaf under flag leaf. $\mathrm{DAA}=$ days after application. Anni moderately resistant, Barke moderately susceptible, Extract susceptible to net blotch. I LSD0.05 $=2.54$ 
Sooväli, P. Fungicide tebuconazole in barley

Net blotch, \% of L2 area diseased 2005

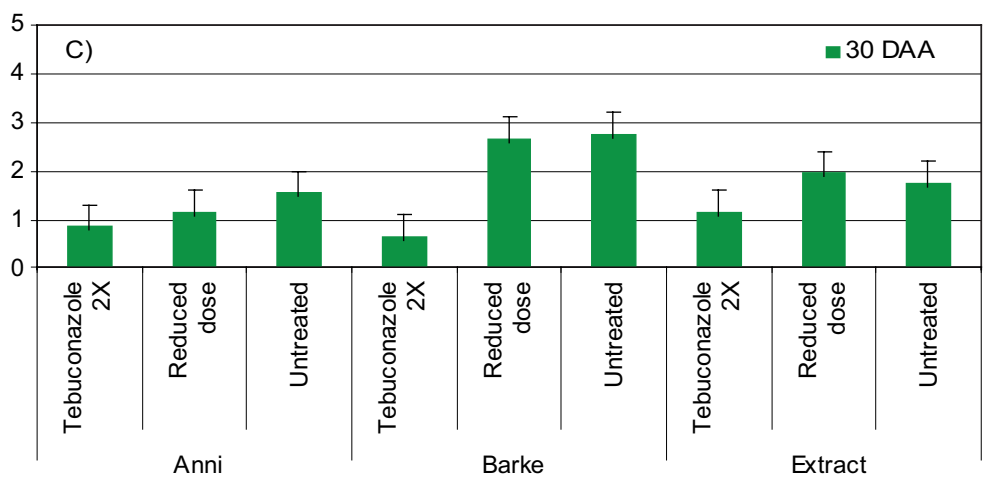

Anni
Extract
Fig. 1c. Efficacy of tebuconazole application against $P$. teres and untreated control on L2 leaves in spring barley varieties. L2 = first leaf under flag leaf. DAA = days after application. Anni moderately resistant, Barke moderately susceptible, Extract susceptible to net blotch. $\mathrm{I}-\mathrm{LSD} 0.05=0.51$.

Spot blotch, \% of L2 area diseased 2003-2005, 30 DAA

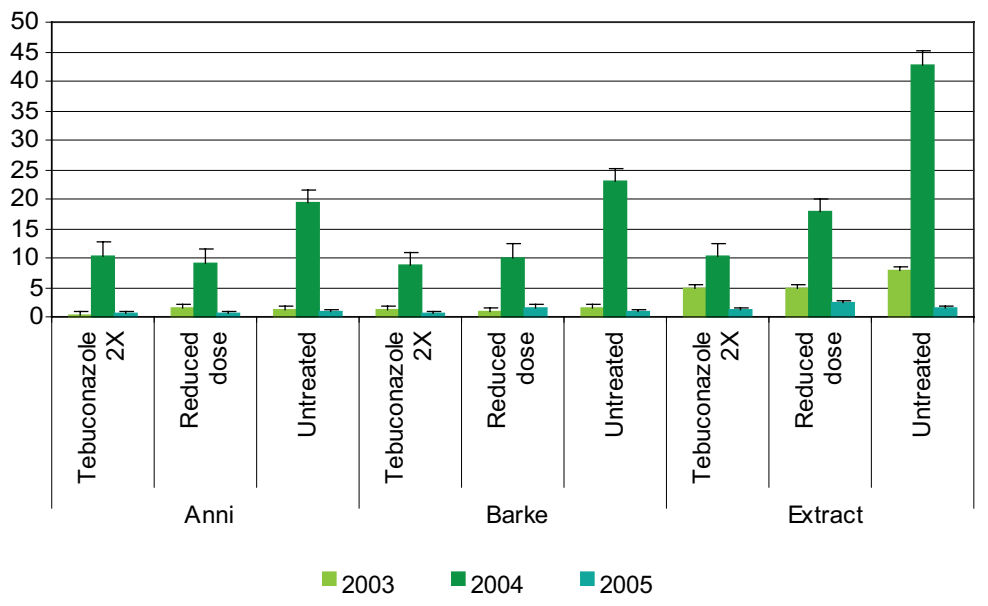

Fig. 2. Efficacy of tebuconazole application against C. sativus and untreated control on L2 leaves in spring barley varieties during 2003-2005.

L2 = first leaf under flag leaf. DAA $=$ days after first treatment. Anni moderately resistant, Barke moderately susceptible, Extract susceptible to spot blotch. I - LSD0.05 = 0.71 (2003); 2.25 (2004); 0.42 (2005).

\section{Effect of fungicide application on disease control}

As expected, the best disease control effect was achieved with two treatments per season. Two fungicide applications were needed in 2004 to control severe disease pressure. Also in conditions of low disease infection in 2005, split application of Folicur $250 \mathrm{EW}$ resulted in significantly better disease control effect than the use of reduced dose according to $\mathrm{PC}-\mathrm{P}$. Application of reduced fungicide dose according to PC-P was sufficient to control the spread of $P$. teres and C. sativus in spring barley in 2003 when the right timing for the application and the optimal dose for the disease pressure were chosen.

Effect of different factors on disease incidence. Results of ANOVA verified that the impact of the year had the biggest influence on the infection intensity of $P$. teres and C. sativus (Table 2). The year and treatment were major factors determining the infection level with $P$. teres. The infection level with $C$. sativus was mostly determined by year, variety and year by variety interactions. Other factors' influence on the infection level was smaller. The coefficients of determination indicate that environmental and genetic factors' contribution to the occurrence of $P$. teres was $72 \%\left(\mathrm{R}^{2}=0.72\right)$. The occurrence of $C$.sativus was less dependent on environmental and genetic factors $\left(\mathrm{R}^{2}=0.46\right)$. The rest is related to some other factors. 
Vol. 18 (2009): 34-42.

Table 2. Mean squares of ANOVA of infection data of P. teres and C. sativus.

\begin{tabular}{lcccc}
\hline & Net blotch & $p>\mathrm{F}$ & Spot blotch & $p>\mathrm{F}$ \\
\hline Treatment & 20.8 & 0.000 & 4.0 & 0.000 \\
Year & 58.0 & 0.000 & 38.8 & 0.000 \\
Variety & 7.7 & 0.000 & 37.0 & 0.000 \\
Year by treatment & 8.7 & 0.000 & 2.0 & 0.000 \\
Year by variety & 2.8 & 0.000 & 16.4 & 0.000 \\
Year by variety by treatment & 2.1 & 0.000 & 1.8 & 0.000 \\
$\mathrm{R}^{2}$ & 0.7236 & & 0.4608 & \\
\hline
\end{tabular}

\section{Grain yield}

The intensity of plant protection caused significant differentiation in yields of tested varieties by treatment variants (Fig. 3). Two applications with the half-dose of tebuconazole improved disease control and resulted in the best yield in all varieties in all years. In all years, the split-treatment strategy brought about higher yield increase for more susceptible varieties Barke and Extract. Yield increase resulting from $\mathrm{PC}-\mathrm{P}$-based fungicide application was significantly lower than that from split application. The moderately resistant variety Anni had relatively low returns on both treatment regimes because of the much higher level of biological resistance.
Fungicide impact on net revenue. Comparing the economic benefit of the extra yield produced by the barley varieties treated by the two strategies, the net yield of moderately resistant variety Anni did not increase, but was even reduced in result of PC-P treatment (Table 3). The yields of the other varieties were equal to or exceeded the control crop. In accordance with these results, we have to examine the possibility that use of fungicides at later growth stages may reduce yield formation in more resistant varieties. Because of low disease pressure, the use of fungicides was not profitable on any of the varieties in 2005 .

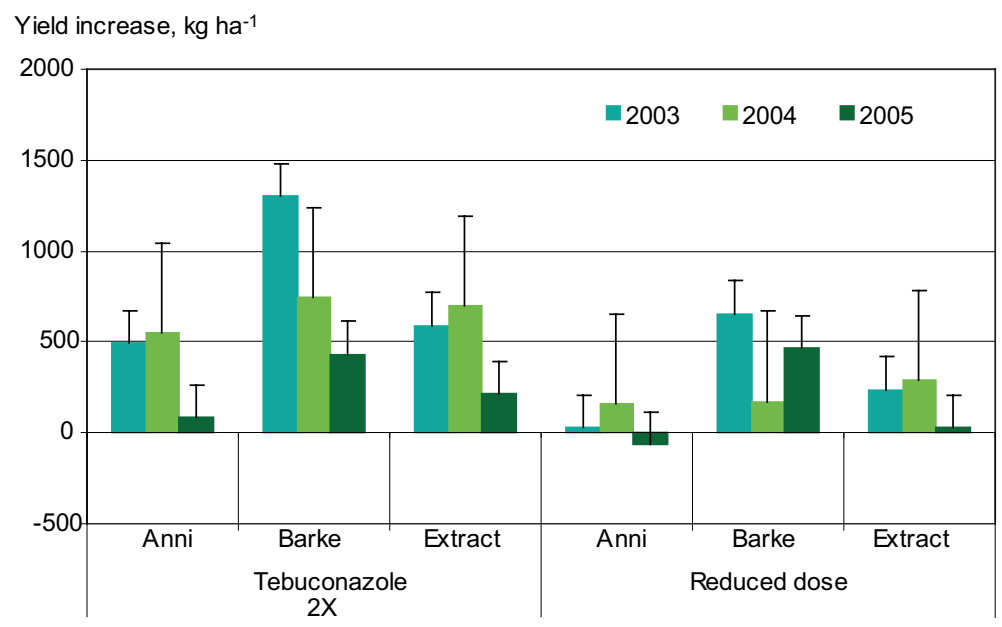

Fig. 3. Yield increase $\mathrm{kg} \mathrm{ha}^{-1}$ in fungicide treated variants in comparison with untreated control crop in 2003-2005.

I - LSD0.05 = 182 (2003); 494 (2004); 178 (2005). Yields of untreated control crop $\left(\mathrm{kg} \mathrm{ha}^{-1}\right)$ in the trials were 1) in 2003: Anni 4451, Barke 3356, Extract 3693, 2) in 2004: Anni 5924, Barke 3452, Extract 4869, 3) in 2005: Anni 4980, Barke 4012, Extract 4271. 
Sooväli, P. Fungicide tebuconazole in barley

Table 3. Yield profit in terms of money (EUR ha $\left.{ }^{-1}\right)$ of spring barley varieties in 2003-005.

\begin{tabular}{|c|c|c|c|c|c|c|c|}
\hline \multirow[t]{2}{*}{ Variety } & & \multicolumn{2}{|c|}{ Net yield kg/ha } & \multicolumn{2}{|c|}{ Net revenue EUR } & \multicolumn{2}{|c|}{$\begin{array}{l}\text { Benefit in monetary terms } \\
\text { EUR/ha }\end{array}$} \\
\hline & & $\begin{array}{c}\text { Tebuconazole } \\
2 \mathrm{X}\end{array}$ & $\begin{array}{l}\text { Reduced } \\
\text { dose }\end{array}$ & $\begin{array}{c}\text { Tebuconazole } \\
2 \mathrm{X}\end{array}$ & $\begin{array}{c}\text { Reduced } \\
\text { dose }\end{array}$ & $\begin{array}{l}\text { Tebuconazole } \\
2 \mathrm{X} \\
\end{array}$ & $\begin{array}{c}\text { Reduced } \\
\text { dose }\end{array}$ \\
\hline \multirow[t]{3}{*}{ Anni } & 2003 & 4419 & 4320 & 442 & 432 & -8 & -16 \\
\hline & 2004 & 5945 & 5120 & 595 & 512 & -4 & -73 \\
\hline & 2005 & 4543 & 4838 & 454 & 484 & -42 & -15 \\
\hline \multirow[t]{3}{*}{ Barke } & 2003 & 4133 & 3852 & 413 & 385 & 59 & 37 \\
\hline & 2004 & 3675 & 3541 & 368 & 354 & 13 & 1 \\
\hline & 2005 & 3920 & 4399 & 392 & 440 & -13 & 29 \\
\hline \multirow[t]{3}{*}{ Extract } & 2003 & 3760 & 3772 & 376 & 377 & 0.3 & 2 \\
\hline & 2004 & 5046 & 5072 & 505 & 507 & 9 & 11 \\
\hline & 2005 & 3963 & 4218 & 396 & 422 & -31 & -8 \\
\hline
\end{tabular}

Anni moderately resistant, Barke moderately susceptible, Extract susceptible to net and spot blotch; Net yield = harvest yield minus the cost of fungicide and application. Price of chemical control 49 (Tebuconazole 2x); 18 (Reduced dose 2003); 13 (Reduced dose 2004); 10 (Reduced dose 2005) EUR/ha.

\section{Discussion}

In recent years, intensive cereal cultivation with limited crop rotation and suitable seasonal weather factors have increased the occurrence of net blotch and, to a lesser extent, spot blotch infection in spring barley. Chemical control measures are needed to avoid yield reduction by disease infections. To achieve economic profitability, it is important to deploy integrated pest management practices among production methods. In the future, the tendency will probably be towards management of disease control under integrated protection methods whereby the fungicide dose and time of application are calculated based on the resistance level of the variety, the prevailing weather conditions and infection situation in the field, taking into account economic profitability. It has been found in the UK that fungicide treatment is effective when the infection level is visually more than 5\% of leaf area (Cook et al. 1999), thus indicating that in the case of low-intensity infection, yield loss is smaller than the cost of fungicide application. Infection level of a specific variety may exceed the infection threshold because of weather conditions and/or susceptibility. For effective control and maximal net yield, the minimal dose of fungicide may be smaller than the standard dose, if adjusted at the point of time when the disease normally emerges.

According to Jørgensen et al. (1996), Hardwick et al. (2000), Henriksen et al. (2000), and Jørgensen et al. (2003) it was found that the use of reduced fungicide doses was effective depending on the weather conditions of the year and on the resistance level of the variety. The PC-P system has previously been described to combine information on thresholds with recommendations for treatments using adjusted fungicide dose (Jørgensen et al. 1996, Henriksen et al. 2000, Jørgensen et al. 2003).

The results of this trial showed that the yield had tendency to display high returns upon application of high fungicide rates, but the high costs of fungicide application reduced the net revenue. Intensive protection was important for barley yielding but the integrated plant protection system was more economical, as the use of PC-P method enables to lower direct costs. Danish trials (Jørgensen et al. 2000) have produced similar results. In our trials, the PC-P variants had significantly higher net yields in 2005, in conditions of low disease infection. This indicates that the fungicide dose may be lowered to achieve disease control but has to be applied at the proper time to be highly effective. 
Vol. 18 (2009): 34-42.

It is important to note that fungicide application is, in many cases (low disease pressure, resistant cultivar), not profitable for the farmer and the correct decision would be to refrain from it. In order to predict the need of fungicide use, it is important to use a DSS, e.g. PC-P. Comparison of fungicides on the market for spring barley in Finland in 2006 has shown that fungicide applications did not improve net revenue in any of the spring barley trials during the dry season of 2006, how ever the negative effect compared to the untreated plots was not significant either (Laine et al. 2007). Trial results from Bavaria also indicate that in years less favorable for disease development, disease control in spring barley can result in negative net revenue (Tischner and Schenkel 2006).

Our trials demonstrated a significant impact of variety resistance on net revenue. Fungicide use in the moderately resistant variety Anni resulted in negative net revenue for all years and doses, the moderately susceptible variety Barke produced the highest and significant net returns and the susceptible variety Extract produced medium net revenue. The variety's tolerance towards disease infection could be a reason for differences in net yield between the studied varieties. According to definition, tolerance is an ability of plants to endure severe disease without severe losses in yield and quality (Schafer 1971). Yield reduction in the variety Anni seems to be lower than could be expected based on the disease infection level and therefore chemical control is too costly for this variety. On the other hand, disease infection seems to cause more severe yield reduction for the susceptible variety Extract than could be compensated by fungicide application. Trials performed in Finland have also shown that the relationship between net blotch symptom expression and yield maintenance in spring barley genotypes was stronger in the case of higher yields and less severe net blotch infection. In conditions of lower yields and/or severe disease infection, the relation between the level of disease infection, yield losses and net revenue was less clear (Robinson 2000).

Multiyear trials in Northern Ireland with a range of fungicides, applied at a range of doses, have demonstrated that the overall profitability was higher for resistant cultivars than for susceptible cultivars and that treatment of resistant cultivars with fungicides did not significantly increase profitability of winter wheat and spring barley any further (Mercer and Ruddock 2002, 2005). Results indicate that the potential of disease resistance of cultivars should be fully exploited and prophylactic spraying is unlikely to be profitable (Mercer and Ruddock 2002).

Our previous trials on spring wheat have shown that chemical disease control is most complicated in relation to moderately susceptible varieties grown in conditions of medium disease pressure (Koppel et al. 2003). Results of the current study indicate that chemical control is most profitable for moderately susceptible spring barley varieties with the use of different fungicide doses, thus differing from the chemical disease control of spring wheat. DSS programs should take more account of relations between severity of disease symptoms and yield reduction.

\section{References}

Agrobase $^{\mathrm{TM}}$ 20. The Software Solution for Plant Breeders. 1999. Addendum and Instructional Guide. Winnipeg, Manitoba. 95 p.

Cook, R.J., Hims, M.J. \& Vaughan, T.B. 1999. Effects of fungicide spray timing on winter wheat disease control. Plant Pathology 48: 33-50.

Fetch, T.G. and Steffenson, B.J. 1999. Rating scales for assessing infection responses of barley infected with Cochliobolus sativus. Plant Disease 83: 213-217.

Hardwick, N.V., Slough, J.E. \& Jones, D.R. 2000. Cereal disease control - are fungicides the sole answer? Proceeding of the International Conference on Pests and Diseases 13-16 Nov 2000, Brighton, England. Pests and Diseases 2000, Vol. 2: 647-654.

Henriksen, K.E., Jørgensen, L.N. \& Nielsen, G.C. 2000. PC-Plant Protection - a Danish tool to reduce fungicide input in cereals. Proceeding of BCPC Conference: Pests and Diseases 2000, Vol. 3: 835-840.

Jørgensen, L.N. 2006. Bekǽmpelse af svampesygdomme I korn. In: Pesticideafprovning 2006. DJF rapport nr. 129: 21-70. (in Danish)

Jørgensen, L.N., Hagelskjaer, L. \& Nielsen, G.C. 2003. Adjusting the fungicide input in winter wheat depending on variety resistance. Proceeding of BCPC International Congress Crop Science \& Technology 2003, Vol. 2: 1115-1120.

Jørgensen, L.N., Henriksen, K.E. \& Nielsen, G.C. 2000. 


\section{AGRICULTURAL AND FOOD SCIENCE}

\section{Sooväli, P. Fungicide tebuconazole in barley}

Margin over cost in disease management in winter wheat and spring barley in Denmark. Proceeding of BCPC Conference: Pests and Diseases 2000, Vol. 2: 655-662.

Jørgensen, L.N., Secher, B.J.M. \& Nielsen, G.C. 1996 Monitoring diseases of winter wheat on both a field and a national level in Denmark. Crop Protection 15: 383-390.

Koppel, M., Runno, E., Sooväli, P., Lauringson, E., Talgre, L. \& Nurmekivi, H. 2003. Control of spring wheat diseases in meteorologically different conditions. Proceedings of the Crop Protection Conference for the Baltic Sea Region, Poznan, p. 142-148.

Laine, P., Jalli, M. \& Hannukkala, A. 2007. Fungicides in field crops. In: Marja Jalli, Jarmo Ketola, Päivi Koski and Peppi Laine (eds). Trial Report: Fungicides and Insecticides, MTT Agrifood Research Finland. Jokioinen, MTT. $33 \mathrm{p}$.

Mathre, D.E. 1997. Compendium of Barley Diseases. 2nd ed. The American Phytopathological Society, St. Paul, MN. 90 p.

Mercer, P.C. \& Ruddock, A. 2002. Disease management of spring barley with reduced doses of fungicides in Northern Ireland. Crop Protection 22: 79-85.

Mercer, P.C. \& Ruddock, A. 2005.Disease management of winter wheat with reduced doses of fungicides in North- ern Ireland. Crop Protection 24: 221-228.

Palmer, G.H. 1989. Cereals in Malting and Brewing. Cereal Science and Technology. Aberdeen: University Press. p. 61-243.

Robinson, J. 2000. Yield of doubled haploid lines of Nordic spring barley infected with net blotch, Pyrenophora teres. Plant Breeding 119: 219-222.

Schafer, J. 1971. Tolerance to plant disease. Annual Review of Phytopathology 9: 235-252.

Statistical Database. 2007. Available on the internet: http// www.stat.ee. Cited on 15.09.2007.

Tamm, Ü. 2003. Genetic resources in malting barley breeding. The Thesis for applying the doctor's degree in agricultural sciences in plant production. Tartu: 68-84. (in Estonian)

Tekauz, A. 1986. Effect of plant age and leaf positionon the reaction of barley to Pyrenophora teres. Canadian Journal of Plant Pathology 8: 380-386.

Tischner, H. \& Schenkel, B. 2006. Entscheidungsmodelle zur gezielten Schadpilzbekämpfung in Sommergerste. Versuch 812. In: Versuchsergebnisse aus Bayern. 2006. Getreide. Bayerische Landesanstalt für Landwirtschaft. Institut für Pflanzenschutz, Freising-Weihenstephan. 16 p. (in Germany) 